\title{
IMPACT OF FERTILIZATION ON AGROFORESTRY SYSTEM COMBINING ROWS OF WILD CHERRY AND SMALL-LEAVED LIME WITH PERENNIAL GRASSES AND LEGUMES IN LATVIA
}

\begin{abstract}
Andis BĀRDULIS, Latvian State Forest Research Institute "Silava", Rigas str. 111, Salaspils, Latvia, LV-2169, andis.bardulis@silava.lv (coresponding author)

Sarmīte RANCĀNE, Latvia University of Life Sciences and Technologies, Research Institute of Agronomy, J.Purapukes str. 28, Skriveri, Latvia, LV-5125, sarmite.rancane@1lu.lv

Mudrìte DAUGAVIETE, Latvian State Forest Research Institute "Silava", Rigas str. 111, Salaspils, Latvia, LV-2169, mudrite.daugaviete@silava.lv

Santa CELMA, Latvian State Forest Research Institute "Silava”, Rigas str. 111, Salaspils, Latvia, LV-2169, santa.celma@ silava.lv Dagnija LAZDIN,A, Latvian State Forest Research Institute "Silava", Rigas str. 111, Salaspils, Latvia, LV-2169, dagnija.lazdina@silava.lv

Interest in agroforestry as land use practice continues to revive due to it's social, economic, and especially environmental and climate change mitigation benefits. This article encompasses results of productivity of hemiboreal agroforestry system combining rows of wild cherry and small-leaved lime with perennial grasses (Phalaris arundinacea L. and Festulolium pabulare) and legumes (Galega orientalis Lam.). Experimental plot of agroforestry system was established in agricultural land on mineral soil in central part of Latvia in the spring of 2011. Different fertilizers such as by-products of bioenergy production (wood ash, digestate), municipal waste (wastewater sludge) and mineral fertilizers were used to compensate nutrients in the soil and soil buffer capacity. Survival rate of the trees (especially for wild cherry) in agroforestry systems was relatively very low, mostly due to winter frosts and later browsing by hares. Nevertheless, results of our study highlighted that both used fertilizers and interactions between trees and herbaceous plants impact total productivity of system including tree growth, yields of biomass and seeds of herbaceous plants as well as chemical composition of biomass of herbaceous plants. Whereas obtained biomass of herbaceous plants can be used for both forage and energy production purposes, the benefits and risks of fertilization must be assessed on a case-by-case basis depending on the intended use of biomass.
\end{abstract}

Keywords: agrisilvicultural system, alley cropping, fertilization, wild cherry, small-leaved lime, herbaceous plants

\section{INTRODUCTION}

The Food and Agriculture Organization (FAO) of the United Nations defines agroforestry as 'land-use systems and technologies where woody perennials are deliberately used on the same land-management units as agricultural crops and/or animals, in some form of spatial arrangement or temporal sequence' (FAO, 2021). A similar definitions of agroforestry are adopted by the World Agroforestry Centre (ICRAF), the European Agroforestry Federation (EURAF) and other organizations and are basically based on Nair (1993), Leakey (1996), and Mosquera-Losada et al. (2009). In general, agroforestry is a relatively new designation for an ancient land use practice of maintaining and integrating trees into agricultural landscapes (Nair, 1993; Den Herder et al, 2015; FAO, 2021). The history of agroforestry varies greatly across different regions of the world (FAO, 2021). In Europe, intensification of agriculture and forestry since the 1960s led to disappearance of many traditional agroforestry systems (Den Herder et al, 2015). Nevertheless, interest in different types of agroforestry continues to revive nowadays (Den Herder et al, 2015) due to social, economic, environmental and climate change mitigation benefits provided by this land use practice (e.g., Daugaviete et al., 2015; Mosquera-Losada et al., 2018; Jose, 2019; Pantera et al., 2021). In Europe, the growing role of agroforestry in land use practice is marked by its definition and mention in regulations, policies and strategies of the European Union (EU) (e.g., Regulation (EU) No 1305/2013, the Common Agricultural policy (CAP) 2023-2027, the new EU Forest Strategy for 2030). Agroforestry has a high potential to contribute to achieving the EU's biodiversity objectives (e.g., Udawatta et al., 2019) as well as greenhouse gas $(\mathrm{GHG})$ emission reduction target, having the ability to sequester atmospheric carbon dioxide $\left(\mathrm{CO}_{2}\right)$ in living biomass and soil (e.g., Aertsens et al., 2013; De Stefano, Jacobson, 2017). In Latvia, national legislation that implements international policy and strategical plans, does not define agroforestry, so far.

Copyright (C) 2021 The Authors. Published by Vytautas Magnus University. This is an open-access article distributed under the terms of the Creative Commons Attribution License (CC BY 4.0), which permits unrestricted use, distribution, and reproduction in any medium, provided the original author and source are credited. 
One of the main types of agroforestry systems is agrisilvicultural systems combining trees with agricultural crops (including alley cropping, hedgerow intercropping, multipurpose trees on crop lands, plantation crop combinations, trees in soil conservation and reclamation, shelterbelts and windbreaks, live hedges, fuelwood production and other combinations of trees and agricultural crops) (Nair, 1993; FAO, 2021). Although agroforestry on cropland is not a common practice in the Baltic States, the tree cover analysis on agricultural land in the Baltic States revealed surprisingly high tree covers density -in total about 1.2 million hectares of agricultural land, with more than $10 \%$ tree cover (Den Herder et al., 2016). In Latvia, alley cropping systems combining rows of fast growing trees (for example, hybrid aspen, poplar or willow) or high value trees (for example, apple, pear, cherry, nuts) with agricultural crops exists only at the experimental field level at present. But it is projected that through international climate change mitigation policy (e.g., Paris Agreement) and new agricultural policy (e.g., CAP 2023-2027) wider adoption of agroforestry and in particular alley cropping could be expected.

The aim of the study is to 1) demonstrate hemiboreal agroforestry system combining rows of wild cherry and small-leaved lime with perennial grasses and legumes in cropland in Latvia and 2) evaluate impact of initial application of different fertilizers including wastewater sludge and by-products of bioenergy production (wood ash and digestate) on tree height as well as on biomass and seed yields of perennial grasses and legumes.

\section{RESEARCH METHODS}

Research site. Research was conducted in central part of Latvia (Skriveri parish, $56^{\circ} 41 \mathrm{~N}$ and $25^{\circ} 08 \mathrm{E}$ ). Experimental plot consisting of subplots of agroforestry systems combining trees and herbaceous plants and subplots of herbaceous plants cultivated as monoculture was established in agricultural land in the spring of 2011. Soil types in the experimental plot were Luvic Stagnic Phaeozem, Hypoalbic and Mollic Stagnosol, Ruptic, Calcaric, Endosiltic according to the World reference base for soil resources 2006. The dominant class of soil texture was loam at 0-20 cm depth and loamy sand at 20-80 cm depth. The experimental plot was fenced in autumn 2012.

Planting material and design. One to two years old bare root seedlings of small-leaved lime (Tilia cordata Mill.) and one year old container seedlings of two different clones (No. 10 and No. 13) of wild cherry (Cerasus avium (L.) Moench) were planted in agroforestry system (distance between trees was $2.5 \times 5.0 \mathrm{~m}$ ). Origin of seedlings of small-leaved lime - mature stand in central part of Latvia (Zemgale region). Producer of plant material of wild cherry - JSC “Latvia's State Forests” nursery "Kalsnava”, Latvia. Between the $5 \mathrm{~m}$ tree rows, one legume (Galega orientalis Lam. 'Gale') and two perennial grasses cultivars (Phalaris arundinacea L. 'Bamse' and Festulolium pabulare 'Felina') were sown (seeding rates - 12, 10 and $12 \mathrm{~kg}$ germinating seeds ha ${ }^{-1}$, respectively) in $2.5 \mathrm{~m}$ wide strips for seed production. Four replications of subplots of each type of agroforestry systems were established. In addition, monoculture trials of mentioned herbaceous plants (without tree rows) were sowed (seeding rates $-30,15 \mathrm{and} 12 \mathrm{~kg}$ germinating seeds $\mathrm{ha}^{-1}$, respectively) for biomass production in randomized block design with four replications and a harvest plot of $20 \mathrm{~m}^{2}$. Galega orientalis Lam. seeds before sowing were treated with nodule bacteria (Rhizobium galegae) propagated on agar. Sowing of herbaceous plants for seed production in agroforestry system was carried out in mid-June of 2011, but sowing of herbaceous plants for biomass production (monoculture trials) was carried out in mid-July of 2011 using the experimental seeder 'Nordsten NS-1025'. Herbaceous plants were sown without a cover crop using a narrow row spacing $(15 \mathrm{~cm})$ for all species in the monoculture trials and for Phalaris arundinacea L. and Festulolium pabulare in agroforestry trials, and broad row spacing $(36 \mathrm{~cm})$ for Galega orientalis Lam. in agroforestry trials.

Fertilization treatments. Different types of nutrient and soil buffer capacity compensatory fertilizers including wastewater sludge, renewable energy by-products (stabilized wood ash and digestate from methane reactor) and mineral fertilizers were applied to improve soil quality (Table 1). Origin of wood ash was boiler house in Sigulda (Latvia), origin of digestate - methane reactor in Vecauce district (Latvia), and origin of wastewater sludge - Ltd. "Aizkraukle Water" (Latvia). Wood ash and wastewater sludge fertilizers were applied shortly before the planting of tree seedlings in spring 2011, but digestate in monoculture trials of herbaceous plants was applied immediately before sowing and every spring of the production years. Mineral fertilizers were applied at the early spring of production years. In addition, control plots were established where no fertilizers were applied. Four replications of each fertilization subplot were conducted.

Measurements and chemical analysis. Tree height measurements were done in 2018 (after the end of the growing season). Herbaceous plant seeds were collected using a small experimental harvester Wintersteiger. To determine dry biomass (DM) of herbaceous plants two harvest regimes were applied - three cuts per year and one delayed cut at the senescence of herbaceous plants (in October) using green mass harvester 'Hege 212'.

The ash, total sulphur $(\mathrm{S})$, nitrogen $(\mathrm{N})$, potassium $(\mathrm{K})$ and phosphorus $(\mathrm{P})$ content in biomass samples of perennial herbaceous plants (the first production year, cutting frequency - three cuts $\mathrm{yr}^{-1}$ ) was determined in the Forest Environment Laboratory at the Latvian State Forest Research Institute "Silava". The ash content was determined according to LVS CEN/TS 14775:2004, the S content was determined using elemental analysis method according to LVS ISO 10694:2006, the $\mathrm{N}$ content was determined using the modified Kjeldahl method according to LVS ISO 11261:2002 L, the K content was determined using flame atomic absorption spectroscopy method (LVS ISO 9964-3:2000 L) and P content was determined using spectrophotometry method according to LVS 398:2002. Content of neutral detergent fiber (NDF) and acid detergent fiber (ADF) in biomass samples were determined using gravimetrical method, crude protein content was 
calculated using coefficient (N,\%*6.25coef). Net energy for lactation (NEL) was calculated according to the methodology for herbaceous plants (Siliņa et al., 2013).

Statistical analysis.All statistical analyses were carried out using R. Pairwise t-tests (pairwise comparisons using t-tests with pooled standard deviations (SD)) were used to evaluate differences in tree height between different fertilization trials. Statistically significant differences in biomass and seed yields of perennial herbaceous plants between the fertilization trials were estimated based on limited standard differences with confidence of 95\% (LSD 0.05).

Table 1. Summary of fertilization treatments.

\begin{tabular}{|c|c|c|c|c|c|c|}
\hline \multirow{2}{*}{$\begin{array}{l}\text { Component of } \\
\text { agroforestry } \\
\text { system or } \\
\text { monoculture }\end{array}$} & \multirow{2}{*}{ Type of fertilizer } & \multirow{2}{*}{ Dose, fertilization frequency } & \multicolumn{3}{|c|}{$\begin{array}{l}\text { Input of nutrients through } \\
\text { fertilization, } \mathrm{kg} \mathrm{ha}^{-1}\end{array}$} & \multirow{2}{*}{$\begin{array}{l}\text { Number of } \\
\text { replications/ } \\
\text { size of each } \\
\text { plot }\end{array}$} \\
\hline & & & total $N$ & total P & total $\mathrm{K}$ & \\
\hline \multirow{4}{*}{$\begin{array}{l}\text { Tree rows in } \\
\text { agroforestry } \\
\text { system }\end{array}$} & Stabilized wood ash (WA) & $6 \mathrm{t} \mathrm{DM} \mathrm{ha}^{-1}$, once initially & 2.6 & 65 & 190 & $4 / 720 \mathrm{~m}^{2}$ \\
\hline & Wastewater sludge (WWS) & $10 \mathrm{t} \mathrm{DM} \mathrm{ha}^{-1}$, once initially & 259 & 163 & 22 & $4 / 720 \mathrm{~m}^{2}$ \\
\hline & $\begin{array}{l}\text { Control }(\mathrm{C}) \text {, both tree rows } \\
\text { and herbaceous plant strips } \\
\text { without fertilization }\end{array}$ & - & 0 & 0 & 0 & $4 / 720 \mathrm{~m}^{2}$ \\
\hline & $\begin{array}{l}\text { Control }(\mathrm{C}) \text {, tree rows } \\
\text { without fertilization, related } \\
\text { herbaceous plant strips } \\
\text { fertilized with mineral } \\
\text { fertilizer }\end{array}$ & - & 0 & 0 & 0 & $4 / 720 \mathrm{~m}^{2}$ \\
\hline \multirow{4}{*}{$\begin{array}{l}\text { Herbaceous } \\
\text { plants in } \\
\text { agroforestry } \\
\text { system for seed } \\
\text { production }\end{array}$} & Stabilized wood ash (WA) & $6 \mathrm{t} \mathrm{DM} \mathrm{ha}^{-1}$, once initially & 2.6 & 65 & 190 & $4 / 300 \mathrm{~m}^{2}$ \\
\hline & Wastewater sludge (WWS) & $10 \mathrm{t} \mathrm{DM} \mathrm{ha}^{-1}$, once initially & 259 & 163 & 22 & $4 / 300 \mathrm{~m}^{2}$ \\
\hline & Mineral fertilizer (MF) & $\begin{array}{l}\text { complex mineral fertilizer } \\
(\mathrm{N} 5: \mathrm{P} 10: \mathrm{K} 25) 500 \mathrm{~kg} \mathrm{ha}^{-1} \mathrm{yr}^{-1} \\
\text { for legumes; } \\
\text { complex mineral fertilizer } \\
(\mathrm{N} 5: \mathrm{P} 10: \mathrm{K} 25) 500 \mathrm{~kg} \mathrm{ha}^{-1} \text { and } \\
\text { ammonium nitrate }(\mathrm{N} 34.4 \%) \\
100 \mathrm{~kg} \mathrm{ha}^{-1} \mathrm{yr}^{-1} \text { for grasses }\end{array}$ & $25 / 60$ & 50 & 125 & 4/ $300 \mathrm{~m}^{2}$ \\
\hline & $\begin{array}{l}\text { Control }(\mathrm{C}) \text {, both tree rows } \\
\text { and herbaceous plant strips } \\
\text { without fertilization }\end{array}$ & - & 0 & 0 & 0 & 4/ $300 \mathrm{~m}^{2}$ \\
\hline \multirow{6}{*}{$\begin{array}{l}\text { Herbaceous } \\
\text { plants } \\
\text { cultivated in } \\
\text { monoculture } \\
\text { for biomass } \\
\text { production }\end{array}$} & Stabilized wood ash (WA) & $6 \mathrm{t} \mathrm{DM} \mathrm{ha}^{-1}$, once initially & 2.6 & 65 & 190 & $4 / 20 \mathrm{~m}^{2}$ \\
\hline & $\begin{array}{l}\text { Stabilized wood ash and } \\
\text { mineral fertilizer (WA + } \\
\text { MF) }\end{array}$ & $\begin{array}{l}\text { WA: } 6 \mathrm{t} \mathrm{DM} \mathrm{ha}{ }^{-1} \text {, once initially } \\
\text { MF: ammonium nitrate } \\
(\mathrm{N} 34.4 \%) 198 \mathrm{~kg} \mathrm{ha}^{-1} \mathrm{yr}^{-1} \text { for } \\
\text { grasses }\end{array}$ & $\begin{array}{l}\text { WA: } 2.6 \\
\text { MF: } 67.4\end{array}$ & WA: 65 & WA: 190 & $4 / 20 \mathrm{~m}^{2}$ \\
\hline & Wastewater sludge (WWS) & $10 \mathrm{t} \mathrm{DM} \mathrm{ha}^{-1}$, once initially & 259 & 163 & 22 & $4 / 20 \mathrm{~m}^{2}$ \\
\hline & Digestate (D) & $30 \mathrm{t} \mathrm{ha}^{-1}$, every year & 65 & 12 & 100 & $4 / 20 \mathrm{~m}^{2}$ \\
\hline & Mineral fertilizer (MF) & $\begin{array}{l}\text { complex mineral fertilizer } \\
(\mathrm{N} 5: \mathrm{P} 10: \mathrm{K} 25) 500 \mathrm{~kg} \mathrm{ha}^{-1} \mathrm{yr}^{-1} \\
\text { for legumes; } \\
\text { complex mineral fertilizer } \\
(\mathrm{N} 5: \mathrm{P} 10: \mathrm{K} 25) 500 \mathrm{~kg} \mathrm{ha}^{-1} \text { and } \\
\text { ammonium nitrate }(\mathrm{N} 34.4 \%) \\
130 \mathrm{~kg} \mathrm{ha}^{-1} \mathrm{yr}^{-1} \text { for grasses }\end{array}$ & $25 / 70$ & 50 & 125 & 4/ $20 \mathrm{~m}^{2}$ \\
\hline & $\begin{array}{l}\text { Control (C), without } \\
\text { fertilization }\end{array}$ & - & 0 & 0 & 0 & $4 / 20 \mathrm{~m}^{2}$ \\
\hline
\end{tabular}

\section{RESEARCH RESULTS}

Tree height in agroforestry system.

The data of tree height and survival proportion for wild cherry and small-leaved lime are shown in Figure 1. The proportion of surviving trees is relatively very low for both tree species but especially for wild cherry, mostly due to winter frosts and later browsing by hares. From all planted tree seedlings only $20 \%$ of wild cherry clone No. $10,25 \%$ of wild cherry clone No. 13 and 55\% of small-leaved lime seedlings survived. The highest tree height for small-leaved lime and wild cherry clone No. 10 was observed in plots initially fertilized with wastewater sludge, furthermore the differences in tree height between control plots where fertilizers had not been applied and plots where wastewater sludge had been initially applied were statistically significant $(\mathrm{p}<0.05)$. For wild cherry clone No. 13, the statistically higher trees were observed in plots where tree rows were not fertilized, but related herbaceous plant strips had been fertilized with mineral fertilizer, and in plots fertilized with wastewater sludge, if compared to control plots. 
In additional to impact of applied fertilizers, also type of intercrop species showed effect on tree height. For all fertilization trials, use of legume (Galega orientalis Lam.) as intercrop species in agroforestry system resulted in higher tree height by average of $40 \%$ for wild cherry and $85 \%$ for small-leaved lime if compared to plots of agroforestry system where grasses (Phalaris arundinacea L. and Festulolium pabulare "Felina") were used as intercrop species.
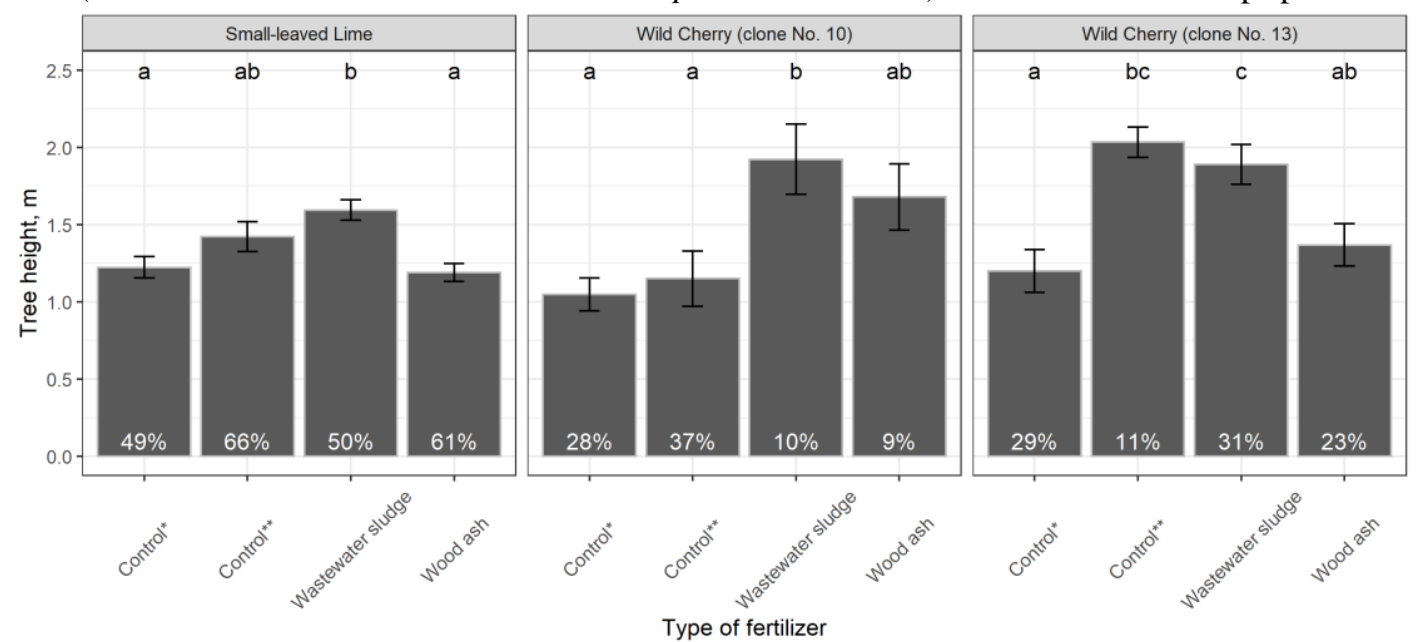

Figure 1. Mean height of wild cherry and small-leaved lime after eight growing seasons since tree planting in agroforestry system. White values in the bars show proportion of surviving trees. Control* - both tree rows and herbaceous plant strips without fertilization; Control** - tree rows without fertilization, but related herbaceous plant strips fertilized with mineral fertilizer. Different letters show statistically significant differences $(p<0.05, \alpha=0.05$ ) in average values between different fertilizers within the same tree species and clone. Error bars show standard errors.

\section{Biomass and seed yields of perennial herbaceous plants}

Average biomass of perennial herbaceous plants in the first and second production year (Figure 2) was in range from $3.2 \mathrm{t} \mathrm{ha}^{-1}$ (Festulolium pabulare, plots fertilized with wood ash, second production year, cutting frequency - one cut per year) to $11.4 \mathrm{t} \mathrm{ha}^{-1}$ (Phalaris arundinacea L., plots fertilized with mineral fertilizer, second production year, cutting frequency - one cut per year). Statistically significant impact of fertilization on biomass of perennial herbaceous plants was observed for most of trials except several plots initially fertilized with wood ash, wastewater sludge or digestate. The highest fertilization impact was observed for Festulolium pabulare in plots fertilized with mineral fertilizer and wood ash + mineral fertilizer (average increase in biomass was $88 \%$ and $82 \%$, respectively).
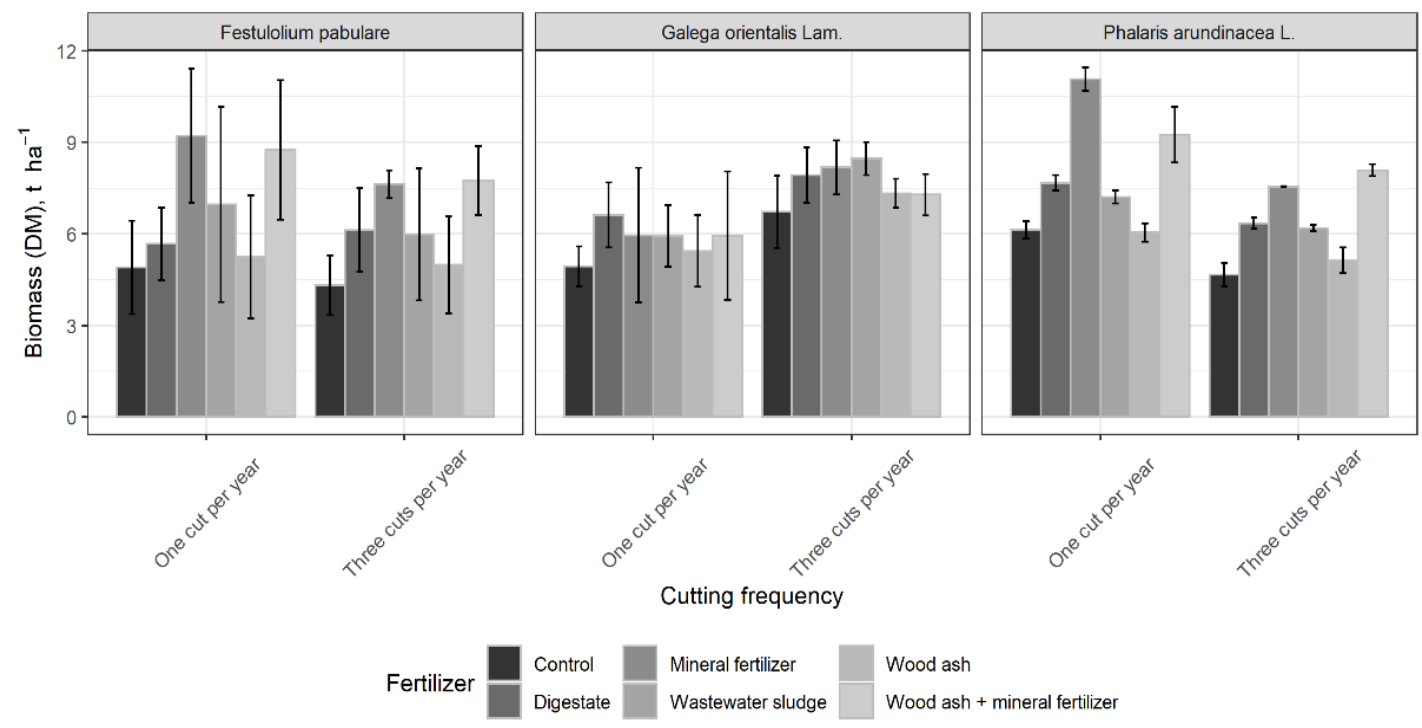

Figure 2. Mean biomass of perennial herbaceous plants cultivated in monoculture in the first and second production year. Error bars show standard errors indicating reliability of the mean values from first and second production year.

In the first and second production year, average seed yield of Festulolium pabulare was in the range from $190.7 \mathrm{~kg} \mathrm{ha}^{-1}$ (plots fertilized with wastewater sludge, second production year) to $1539.17 \mathrm{~kg} \mathrm{ha}^{-1}$ (plots fertilized with mineral fertilizer, first production year), furthermore, seed yield in the first production year was significantly higher than that in the second production year. Average seed yield of Galega orientalis Lam. varied in a narrower range from 141.7 $\mathrm{kg} \mathrm{ha}^{-1}$ (control plots, first production year) to $567.8 \mathrm{~kg} \mathrm{ha}^{-1}$ (plots fertilized with wood ash, second production year), furthermore, seed yield in the second production year was significantly higher than that in the first production year. Average seed yield of Phalaris arundinacea $\mathrm{L}$. varied from $128.9 \mathrm{~kg} \mathrm{ha}^{-1}$ (control plots, first production year) to 436.1 
$\mathrm{kg} \mathrm{ha}^{-1}$ (plots fertilized with mineral fertilizer, second production year) and seed yield in the second production year was significantly higher if compared to the first production year. For Festulolium pabulare and Phalaris arundinacea L. statistically higher seed yield was observed in plots fertilized with mineral fertilizer and wastewater sludge, but for Galega orientalis Lam. statistically higher seed yield was observed in plots fertilized with wood ash if compared to the control plots (Figure 3).

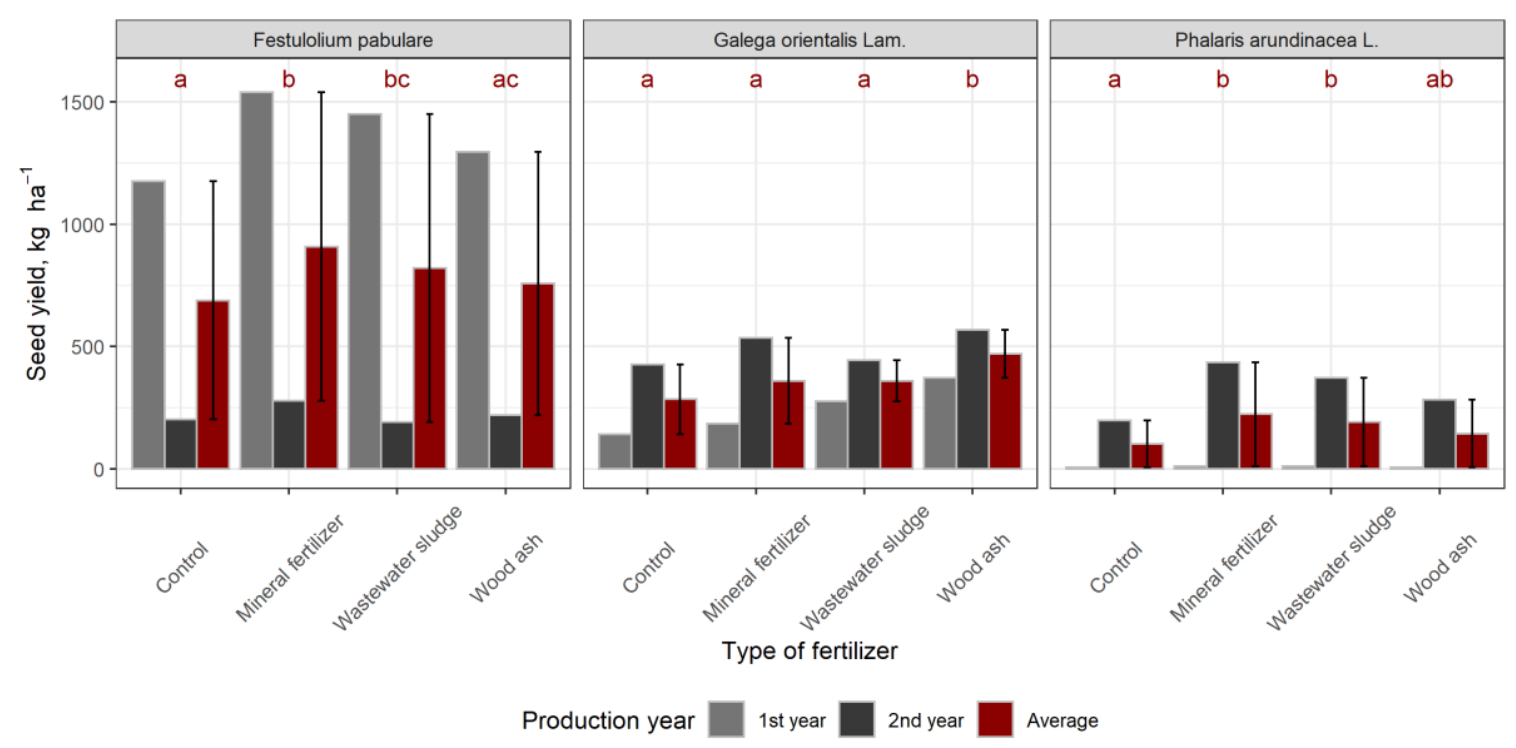

Figure 3. Mean seed yields of perennial herbaceous plants in agroforestry systems in the first and second production year. Error bars show standard errors indicating reliability of the mean values from first and second production year. Different letters show statistically significant differences $(p<0.05, \alpha=0.05)$ in average values between different fertilizers within the same herbaceous plant.

Chemical composition of biomass of perennial herbaceous plants at the first production year is shown in Table 2. The mean ash content of herbaceous plant biomass (dry basis) varies in the interval of 6.5-8.3\% and the highest ash contents was found in biomass of Galega orientalis Lam. for almost all fertilization treatments. Slightly higher S, K and $\mathrm{P}$ contents were found in biomass of grass species (up to $2.5 \mathrm{~g} \mathrm{~kg}^{-1}, 22.7 \mathrm{~g} \mathrm{~kg}^{-1}$ and $2.9 \mathrm{~g} \mathrm{~kg}^{-1}$, respectively), the highest $\mathrm{N}$ and crude protein contents were found in biomass of Galega orientalis Lam. for all fertilization treatments (up to 22.9 $\mathrm{g} \mathrm{kg}^{-1}$ and $15.7 \%$, respectively), but the highest neutral detergent fiber and acid detergent fiber contents were found in biomass of Phalaris arundinacea L. (up to $32.8 \%$ and $37.3 \%$, respectively).

Table 2. Chemical composition of biomass of perennial herbaceous plants at the first production year (cutting frequency - three cuts $\mathrm{yr}^{-1}$ ). Type of fertilizer: $\mathrm{C}$ - control; D - digestate; MF - mineral fertilizer; WA - wood ash; WA+MF - wood ash + mineral fertilizer; WWS - wastewater sludge.

\begin{tabular}{|c|c|c|c|c|c|c|c|c|c|c|}
\hline $\begin{array}{c}\text { Perennial } \\
\text { herbaceous } \\
\text { plants }\end{array}$ & $\begin{array}{c}\text { Type of } \\
\text { fertilizer }\end{array}$ & $\begin{array}{c}\text { Ash } \\
\text { content, } \\
\%\end{array}$ & $\begin{array}{c}\mathrm{S}, \\
\mathrm{g} \mathrm{kg}^{-1}\end{array}$ & $\begin{array}{c}\mathrm{N}, \\
\mathrm{g} \mathrm{kg}^{-1}\end{array}$ & $\begin{array}{c}\mathrm{K}, \\
\mathrm{g} \mathrm{kg}^{-1}\end{array}$ & $\begin{array}{c}\text { P, } \\
\mathrm{g} \mathrm{kg}^{-1}\end{array}$ & $\begin{array}{c}\text { Crude } \\
\text { protein, } \\
\%\end{array}$ & $\begin{array}{c}\text { Neutral } \\
\text { detergent } \\
\text { fiber } \\
\text { (NDF), \% }\end{array}$ & $\begin{array}{c}\text { Acid } \\
\text { detergent } \\
\text { fiber } \\
(\mathrm{ADF}), \%\end{array}$ & $\begin{array}{c}\text { Net energy } \\
\text { lactation } \\
\text { (NEL), } \\
\text { MJ kg-1 }^{-1}\end{array}$ \\
\hline \multirow{6}{*}{$\begin{array}{l}\text { Festulolium } \\
\text { pabulare }\end{array}$} & $\mathrm{C}$ & 6.8 & 1.1 & 10.8 & 18.4 & 2.0 & 7.2 & 28.5 & 32.6 & 6.0 \\
\hline & $\mathrm{D}$ & 6.7 & 1.2 & 10.5 & 19.1 & 2.2 & 7.6 & 28.2 & 32.5 & 6.0 \\
\hline & MF & 7.8 & 1.4 & 12.5 & 20.3 & 2.3 & - & - & - & - \\
\hline & WA & 7.0 & 1.2 & 11.0 & 16.6 & 2.1 & - & - & - & - \\
\hline & $\mathrm{WA}+\mathrm{MF}$ & 7.4 & 1.3 & 13.8 & 18.8 & 2.3 & 9.0 & 27.6 & 32.7 & 6.0 \\
\hline & WWS & 7.4 & 2.1 & 13.3 & 19.1 & 2.5 & 8.6 & 28.3 & 34.2 & 5.6 \\
\hline \multirow{6}{*}{$\begin{array}{l}\text { Phalaris } \\
\text { arundinacea } \\
\text { L. }\end{array}$} & $\mathrm{C}$ & 6.5 & 1.9 & 12.0 & 17.1 & 2.3 & 8.6 & 30.1 & 35.2 & 5.8 \\
\hline & $\mathrm{D}$ & 6.8 & 1.4 & 13.5 & 17.7 & 2.4 & 8.0 & 30.3 & 36.6 & 5.7 \\
\hline & MF & 7.3 & 2.5 & 14.0 & 22.7 & 2.6 & - & - & - & - \\
\hline & WA & 6.7 & 1.7 & 12.4 & 15.4 & 2.2 & - & - & - & - \\
\hline & $\mathrm{WA}+\mathrm{MF}$ & 7.4 & 1.2 & 13.3 & 16.6 & 2.1 & 9.7 & 30.9 & 37.3 & 5.6 \\
\hline & WWS & 6.9 & 1.5 & 13.8 & 19.0 & 2.9 & 8.2 & 32.8 & 37.1 & 5.7 \\
\hline \multirow{6}{*}{$\begin{array}{l}\text { Galega } \\
\text { orientalis } \\
\text { Lam. }\end{array}$} & $\mathrm{C}$ & 7.5 & 1.4 & 20.6 & 13.6 & 2.0 & 13.3 & 26.6 & 29.9 & 6.2 \\
\hline & $\mathrm{D}$ & 7.6 & 1.2 & 19.0 & 17.1 & 2.2 & 12.4 & 28.1 & 32.0 & 6.1 \\
\hline & $\mathrm{MF}$ & 8.3 & 1.8 & 20.9 & 19.5 & 2.1 & - & - & - & - \\
\hline & WA & 7.4 & 1.4 & 21.0 & 15.6 & 2.1 & - & - & - & - \\
\hline & $\mathrm{WA}+\mathrm{MF}$ & 7.0 & 1.3 & 19.0 & 14.8 & 1.9 & 13.3 & 30.1 & 31.0 & 6.1 \\
\hline & WWS & 7.6 & 1.7 & 22.9 & 16.3 & 2.4 & 15.7 & 31.6 & 34.1 & 5.9 \\
\hline
\end{tabular}




\section{CONCLUSIONS AND DISCUSSION}

Agroforestry systems are sustainable land management methods for the production of food and forest products while considering the associations among agroecosystems (Abreu et al., 2016). Ecological interactions between the components of an agroforestry system can influence individual components as well as the whole system (Atangana et al., 2014; Beule, Karlovsky, 2021). A positive interaction is the complementarity between woody and herbaceous components in resource acquisition (Atangana et al., 2014). In additional, fertilizer response in agroforestry system was found by several studies and was found to be most common especially in alley cropping systems (Szott, Kass, 1993) where rows of trees are alternated with rows of annual or perennial agricultural crops (tree-based intercropping) (Beule, Karlovsky, 2021). Furthermore, the use of different byproducts (e.g., wood ash, digestate and wastewater sludge) may be a sustainable alternative to the mineral fertilizers (Abreu et al., 2016).

Results of our study showed significant impact of initial fertilization on tree height after eight growing seasons. For small-leaved lime and wild cherry (clone No. 10), the highest tree height was observed in plots where wastewater sludge had been initially applied $(1.59 \pm 0.07 \mathrm{~m}$ and $1.92 \pm 0.23 \mathrm{~m}$, respectively), but for wild cherry (clone No. 13), the highest tree height was observed in plots where tree rows had not been initially fertilized, but adjacent herbaceous plant strips were fertilized with mineral fertilizer $(2.03 \pm 0.10 \mathrm{~m})$. In additional, positive impact on tree height was observed in subplots of agroforestry systems where $\mathrm{N}$-fixing intercrop species (Galega orientalis Lam.) was cultivated. Previous experiments in agricultural land with naturally dry mineral soils in Latvia showed good growth of small-leaved lime and wild cherry (if stands were intensively tended and protected) with the following mean parameters for 15 years old stands: for wild cherry - height $5.5 \pm 0.81-7.8 \pm 0.53 \mathrm{~m}$, diameter at breast height $(\mathrm{DBH}) 5.2 \pm 1.72-11.4 \pm 2.62 \mathrm{~cm}$; for smallleaved lime - height $3.3 \pm 1.10-8.8 \pm 0.73 \mathrm{~m}, \mathrm{DBH} 4.0 \pm 2.3-11.8 \pm 2.73 \mathrm{~cm}$ (Daugaviete et al., 2015). The need to intensively protect the agroforestry systems was also highlighted by the results of our study (accordingly, trees had relatively very low survival rate).

Similar to the tree height in agroforestry systems, the results of the study indicate a significant impact of fertilization on biomass and seed yields of perennial herbaceous plants as well. This confirms that wood ash and wastewater sludge are a good source of plant nutrients (Insam et al., 2009; Fuzesi et al., 2015) and those can be successfully used as fertilizers in energy plant plantations thus providing yield increase and plant nutrient recycling (Arthurson, 2009; Rancane et al., 2015). The biomass and seed yields of perennial herbaceous plants ranged up to $11.4 \mathrm{t}$ ha $^{-1}$ (biomass of Phalaris arundinacea L., the second production year, cutting frequency - one cut per year) and 1539.2 $\mathrm{kg} \mathrm{ha}^{-1}$ (seed yield of Festulolium pabulare, the first production year), respectively, in plots where mineral fertilizer had been applied. For Festulolium pabulare and Phalaris arundinacea L., the highest fertilization impact on biomass and seed yields was observed in plots fertilized with mineral fertilizer, but for legume (Galega orientalis Lam.) the impact of mineral fertilizer and other fertilizers was less pronounced due to the fact that Galega orientalis Lam. as a legume is able to capture atmospheric $\mathrm{N}$, but the effect of $\mathrm{P}$ and $\mathrm{K}$ is better assessed in the long term. In our agroforestry systems combining rows of wild cherry and small-leaved lime with perennial herbaceous plants (grasses and legumes), both used fertilizers and interactions between trees and herbaceous plants had impact on total productivity of the system (tree growth, yields of herbaceous plants) and thus amount of sequestered atmospheric $\mathrm{CO}_{2}$ in living biomass.

The chemical composition of biomass of herbaceous plants determine advisable use both for energy production (e.g., Lewandowski, Kicherer, 1997; Oleszek et al., 2014; Rancane et al., 2015; Vassilev et al., 2017) and forage purposes (e.g., Meripõld et al., 2017). Results of our study confirmed that the use of fertilizers increases the biomass yields and simultaneously improves parameters determining the quality of biomass for forage, but increased content of inorganic matter and ash-forming elements may contribute to numerous technological and environmental problems during biomass processing as solid fuel. Thus, the benefits and risks of fertilization must be assessed on a case-by-case basis depending on the intended use of biomass of herbaceous plants. Within our study, the evaluation of the chemical composition of biomass of herbaceous plants indicated that biomass of grasses (Festulolium pabulare and Phalaris arundinacea L.) is more suitable for using as solid fuel (for energy production) mostly due to a lower ash content, but biomass of Galega orientalis Lam. is more suitable for forage purposes mostly due to a higher crude protein content and a lower NDF and $\mathrm{ADF}$ content. It should be noted that our results of chemical composition of biomass reflected cutting frequency of three cuts per year, but previous studies in Latvia have shown that a lower ash content and hence more appropriate raw material of herbaceous plants for combustion can be obtained by harvesting herbaceous plants once per season as late as possible in the autumn (Rancane et al., 2015). Thus, the chemical composition of biomass of herbaceous plants is mostly influenced not only by used fertilizers, but also by the cutting regime and selected plant fraction (Rancane et al., 2015).

ACKNOWLEDGMENT. This research was funded by the European Regional Development Fund's Post-doctoral research project "Evaluation of climate change mitigation potential of agroforestry systems with mineral and organic soils" (No. 1.1.1.2/VIAA/4/20/684).

\section{REFERENCES}

1. Abreu S.A.H., Arruda E.M., Barros L.R., de Almeida R.F., Maranhão D.D.C., da Silva V.L., de Melo e Silva Neto C., Flores R.A., Calil F.N., Collier L.S. 2016. Chemical Attributes of the Soil in Agroforestry Systems Subjected to Organic Fertilizations. African Journal of Agricultural Research, Vol. 10(27), pp. 2378-2388. https://doi.org/10.5897/AJAR2016.11182 
2. Aertsens J., De Nocker L., Gobin A. 2013. Valuing the Carbon Sequestration Potential for European Agriculture. Land Use Policy, Vol. 31, pp. 584-594. https://doi.org/10.1016/j.landusepol.2012.09.003

3. Arthurson V. 2009. Closing the Global Energy and Nutrient Cycles through Application of Biogas Residue to Agricultural Land - Potential Benefits and Drawback. Energies, Vol. 2, pp. 226-242. https://doi.org/10.3390/en20200226

4. Atangana A., Khasa D., Chang S., Degrande A. 2014. Ecological Interactions and Productivity in Agroforestry Systems. Springer, Dordrecht. https://doi.org/10.1007/978-94-007-7723-1

5. Beule L., Karlovsky P. 2021. Tree Rows in Temperate Agroforestry Croplands Alter the Composition of Soil Bacterial Communities. PLoS ONE, Vol. 16(2), e0246919. https://doi.org/10.1371/journal.pone.0246919

6. Daugaviete M., Lazdiña D., Bambe B., Bārdule A., Bārdulis A., Daugavietis U. 2015. Productivity of Different Tree Species in Plantations on Agricultural Soils and Related Environmental Impacts. Baltic Forestry, Vol. 21(2), pp. 349-358.

7. De Stefano A., Jacobson,M.G. 2017. Soil Carbon Sequestration in Agroforestry Systems: A Meta-analysis. Agroforestry Systems, Vol. 92(2), pp. 285-299. https://doi.org/10.1007/s10457-017-0147-9

8. Den Herder M., Burgess P.J., Mosquera-Losada M.R., Herzog F., Hartel T., Upson M., Viholainen I., Rosati A. 2015. Preliminary Stratification and Quantification of Agroforestry in Europe. Report 1.1 for EU FP7 AGFORWARD project (613520).

9. Den Herder M., Moreno G., Mosquera-Losad, M.R., Palma J.H.N., Sidiropoulou A., Santiago Freijanes J.J., Crous-Duran J., Paulo J., Tomé M., Pantera A., Papanastasis V., Mantzanas K., Pachana P., Papadopoulos A., Plieninger T., Burgess P.J. 2016. Current Extent and Trends of Agroforestry in the EU27. Report 1.2 for EU FP7 AGFORWARD project (613520).

10. FAO. 2021. Agroforestry. Available at http://www.fao.org/forestry/agroforestry/80338/en/ (accessed on 31/08/2021)

11. Fuzesi I., Heil B., Kovacs G. 2015. Effects of wWood Ash on the Chemical Properties of Soil and Crop Vitality. Acta Silvatica et Lignaria Hungarica, Vol. 11(1), pp. 55-64. https://doi.org/10.1515/aslh-2015-0004

12. Insam H., Franke-Whittle I.H., Knapp B.A., Plank R. 2009. Use of Wood Ash and Anaerobic Sludge for Grassland Fertilization: Effects on Plants and Microbes. Die Bodenkultur, Vol. 60(2), pp. 39-50.

13. Jose S. 2019. Environmental Impacts and Benefits of Agroforestry. The Oxford Encyclopedia of Agriculture and the Environment. Oxford University Press. https://doi.org/10.1093/acrefore/9780199389414.013.195

14. Leakey R. 1996. Definition of Agroforestry Revisited. Agroforestry Today, Vol. 8(1), pp. 5-7.

15. Lewandowski I., Kicherer A. 1997. Combustion Quality of Biomass: Practical Relevance and Experiments to Modify the Biomass Quality of Miscanthus $\mathrm{x}$ giganteus. European Journal of Agronomy, Vol. 6(3-4), pp. 163-177. https://doi.org/10.1016/S1161-0301(96)02044-8

16. Meripõld H., Tamm U., Tamm S., Võsa T., Edesi L. 2017. Fodder Galega (Galega Orientalis Lam) Grass Potential as a Forage and Bioenergy Crop. Agronomy Research, Vol. 15(4), pp. 1693-1699.

17. Mosquera-Losada M.R., McAdam J., Romero-Franco R., Santiago-Freijanes J.J, Riguero-Rodríquez A. 2009. Definitions and Components of Agroforestry Practices in Europe. Agroforestry in Europe: Current Status and Future Prospects. Springer Science + Business Media B.V., Dordrecht.

18. Mosquera-Losada M.R., Santiago-Freijanes J.J., Rois-Díaz M., Moreno G., Den Herder M., Aldrey J.A., Ferreiro-Domínguez N., Pantera A., Pisanelli A., Rigueiro-Rodríguez A. 2018. Agroforestry in Europe: A Land Management Policy Tool to Combat Climate Change. Land Use Policy, Vol. 78, 603-613. https://doi.org/10.1016/j.landusepol.2018.06.052

19. Nair P.K.R. 1993. An introduction to agroforestry. Springer Netherlands. https://doi.org/10.1007/978-94-011-1608-4

20. Oleszek M., Król A., Tys J., Matyka M., Kulik M. 2014. Comparison of Biogas Production From Wild and Cultivated Varieties of Reed Canary Grass. Bioresource Technology, Vol. 156, pp. 303-306. https://doi.org/10.1016/j.biortech.2014.01.055

21. Pantera A., Mosquera-Losada M.R., Herzog F., Den Herder M. 2021. Agroforestry and the Environment. Agroforest Systems, Vol. 95, pp. 767-774. https://doi.org/10.1007/s10457-021-00640-8

22. Rancane S., Karklins A., Lazdina D., Berzins P. 2015. Biomass Yield and Chemical Composition of Perennial Grasses for Energy Production. Engineering for Rural Development, , pp. 546-551.

23. Silina A., Dreijere S., Arbidāns D., Zauers,K. 2013. Lopbarības analī̌̌u rezultātu apkopojums. SIA Latvijas Lauku konsultāciju un izglìtības centrs, Ozolnieki. (In Lavian)

24. Szott L.T., Kass,D.C.L. 1993. Fertilizers in Agroforestry Systems. Agroforest Systems, Vol. 23, pp. 157-176. https://doi.org/10.1007/BF00704913

25. Udawatta R.P., Rankoth L.M., Jose S. 2019. Agroforestry and Biodiversity. Sustainability, Vol. 11 , ID 2879. https://doi.org/10.3390/su11102879

26. Vassilev S.V., Vassileva C.G., Song Y-C., Li W-Y., Feng J. 2017. Ash Contents and Ash-forming Elements of Biomass and Their Significance for Solid Biofuel Combustion. Fuel, Vol. 208, pp. 377-409. https://doi.org/10.1016/j.fuel.2017.07.036 